\title{
Die historiese Jesus as wonderwerker
}

\author{
J Engelbrecht \\ Universiteit van Suid-Afrika
}

\begin{abstract}
The historical Jesus as miracle worker

This paper deals with some introductory aspects of the problem of the historical Jesus as miracle worker. After the attention that the words of Jesus have been receiving over the past few years, the deeds and especially the miracles of Jesus are now on the agenda of researchers. This paper surveys the sources that may be used in this research. It makes some comments on methods of research and finally gives a brief survey of the debate on the historicity of different types of miracle stories.
\end{abstract}

\section{INLEIDING}

Te midde van al die belangstelling in Historiese Jesus-navorsing wat in die laaste aantal jare opnuut opgevlam het, is bitter min aandag gegee aan die wonderdade van Jesus en inderdaad aan die meeste van sy dade soos vertel in die Evangelies. Die klem het tot dusver feitlik volledig op die uitsprake van Jesus geval. Die Jesus Seminar wat in 1985 deur Robert Funk begin is, se werksaamhede het die uitsprake van Jesus deeglik ondersoek en die resultate van hulle navorsing mond uit in die sogenaamde Red-letter edition van die vyf Evangelies (die vier kanonieke Evangelies plus die Evangelie volgens Thomas). In dié uitgawe word die uitsprake van Jesus in vier kleure aangedui: rooi, pienk, grys en swart. Die betekenis van die kleure wissel van woorde wat deur die navorsers van die Jesus Seminar sonder twyfel aan die historiese Jesus toegeskryf word, tot by uitsprake wat volgens hulle mening definitief nie aan Jesus toegeskryf kan word nie. Die volgende saak op die agenda van die Jesus Seminar is die wonders van Jesus - 'n projek waaraan hulle reeds begin werk het, maar nog nie begin publiseer het nie. 
Wat hier volg, moet dus gesien word as enkele inleidende opmerkings om die probleem van wonders in die lewe van die historiese Jesus op die tafel te plaas. Die eintlike werk oor die onderwerp moet nog gedoen word. In hierdie artikel word die volgende sake kortliks aan die orde gestel: Die bronne wat moontlik gebruik kan word in die ondersoek na die wonders van die historiese Jesus, metode, en dan die historisiteit van sekere soorte wonders.

\section{BRONNE}

Vir geruime tyd het die gedagte geleef dat navorsers slegs op die kanonieke evangelies aangewese is vir ondersoeke na die historiese Jesus. Dit is goed bekend dat Paulus en die res van die Nuwe Testament baie suinig is met feite oor die historiese Jesus en meer geinteresseerd is in die verhoogde Here. Wat wonders byvoorbeeld betref, noem Paulus sy eie wonders, maar sê niks oor Jesus se wonders nie.

Wat die Evangelies betref, was navorsers tradisioneel geneig om meer waarde aan die Sinoptiese tradisie toe te ken as aan die Johannese tradisie. Hedrick (1988: 3-4) haal nege uitsprake aan om dit te staaf: uitsprake van Schweitzer, Dibelius, Bultmann, Bornkamm, Stauffer, Conzelmann en Braun. Dit is egter nie duidelik of daar in hierdie uitsprake slegs verwysings is na die woorde van Jesus en of sy wonders daarby ingesluit is nie, aangesien die sogenaamde semeia-bron reeds 'n gevestigde vastrapplek in die navorsing verkry het. Die feit bly egter dat die Sinoptiese tradisie dikwels as die enigste uitgangspunt gebruik is en dan veral die Evangelie volgens Markus. Die volgende uitspraak van Bultmann (1963:111) stel dit duidelik: '[A]nd the task which follows for historical research is this: to separate the various strata in Mark and to determine which belonged to the original historical tradition and which derived from the work of the author.' Al sou die Sinoptiese tradisie bo die Johannese verkies word, sou tog aan die Johannese semeia-bron waarde toegeken moet word in die ondersoek na Jesus se wonders.

In die afgelope ses dekades het die nie-kanonieke bronne oor Jesus egter dramaties toegeneem (vgl Cameron 1982). In 1935 is Papyrus Egerton 2, 'n fragment van 'n vroeë Christelike evangelie, beskikbaar gestel. Dit is vanuit die Nag Hammadi-biblioteek opgevolg deur die Evangelie van Thomas (1959), die Apokrief van Jakobus (1968) en die Dialoog van die Verlosser (1977). Volgens die jongste ondersoeke blyk dit dat die tradisie wat in hierdie tekste voorkom, nie van die Sinoptiese Evangelies stam nie, maar van die vroeë Christelike mondelinge tradisie (vgl Hedrick 1988:5). Daar is vandag redelik algemene instemming dat die publikasie van die Nag Hammadi-biblioteek ' $n$ nuwe era in die ondersoek na die historiese Jesus ingelui het. Hoewel die waarde van Nag Hammadi in die eerste plek lê by die toe- 
voeging van woorde van Jesus, strek die invloed daarvan reeds wyer in die sin dat dit die dissipline van Nuwe-Testamentiese studies ingrypend geraak het.

Die belangstelling in die apokriewe evangelies het ook weer die belangstelling in die literêre bronne van die kanonieke Evangelies laat herleef. Dit bring ook weer die semeia-bron na vore. So kom ook die vraag na 'n voor-Markaanse wonderversameling weer in gedrang, asook die Q-bron en ander bronne van die Evangelieskrywers. Verder moet daar ook aandag gegee word aan die Rabbynse literatuur, Hellenistiese literatuur en natuurlik ook die Ou Testament.

Wat die Rabbynse literatuur betref, het Fiebig (1911) die aandag gevestig op die Rabbynse parallelle met die wonderverhale in die Evangelies. Hy het onder andere gewys op die ooreenkoms in styl en in die soort van wonderverhale: opwekkings uit die dood, verhale oor die see, wonderbaarlike voedings, ontmoetings met demone en wonderbarlike visvangste (Fiebig 1911:74). Daar is egter ook belangrike verskille: In die Nuwe Testament kom geen reënwonder voor nie, terwyl die voorkoms van eksorsismes en genesings van verlamdes en blindes laag is by die Rabbynse verhale.

Fiebig is deur Dibelius daarvan beskuldig dat hy nie erns maak met al die probleme van die Rabbynse literatuur nie. Volgens Dibelius is die Rabbynse wonderverhale hoofsaaklik in twee sake geïnteresseerd: eerstens om deur middel van 'n wonderbaarlike gebeurtenis aan te dui dat God sy goedkeuring gee aan 'n saak wat vir Hom van belang is, byvoorbeeld die onderhouding van die wet, en tweedens vind wonders plaas tot eer van 'n rabbi. Ten spyte van ooreenkomste, is die verskille merkwaardig groot en is 'n verband moeilik voorstelbaar (Dibelius 1933:131-149). Ten opsigie hiervan waarsku Crossan (1988:4) onder die opskrif 'Avoid rabbinic retrojection' met die volgende woorde:

A first principle is that nothing, absolutely nothing, should be taken from the rabbinic corpus unless it is passed through the most careful source criticism to establish its early first century provenance and relevance. What was happening in the second half of the second century must be kept totally separate from what was happening in the first half of the first century.

'n Tweede beginsel wat Crossan (1988:4) stel ten opsigte van die gebruik van Rab. bynse materiaal in die soektog na die historiese Jesus, verdien hier vermelding. Dit is die aanvaarding van die pluralistiese situasie van die vroeg eerste-eeuse Jodedom. Dit beteken dat daar gestreef moet word na 'n saamgestelde voorstelling deur gebruik te maak van simbole en briewe, muntstukke en dokumente, die Bybel en Qumran, apokriewe en pseudepigrafiese literatuur, Filo en Josefus. Dit is vandag bekend dat die Jodedom in die tyd van Jesus baie meer pluralisties was as 'n eeu 
later toe die rabbi's die eenheid wat hulle toé bereik het, so ver as moontlik wou terugprojekteer.

Vermes (1973:223) beskryf Jesus soos volg: 'Jesus did not belong among the Pharisees, Essenes, Zealots or Gnostics, but was one of the holy miracle-workers of Galilee'. Vermes het in navolging van ander die aandag gevestig op Honi die 'sirkelmaker' (ca 63 v C) en 'R Hanina ben Dosa' (ca 40-70 n C). Honi, bekend uit Josefus se geskrifte (Onias, volgens Josefus) en tradisionele Joodse literatuur, was volgens die bronne bekend as 'n heilige man en ook vir sy suksesvolle gebede vir reën (vgl Vermes 1973:69-72). Van R Hanina ben Dosa is baie wonders bekend, nie net genesings nie, maar ook wonders soortgelyk aan die voeding van die vyfduisend en die water-na-wyn van die kanonieke Evangelies. Hy word nie voorgestel as 'n groot leermeester nie, maar eerder as 'n hasid wat vir mense in nood omgee. Die Mishna noem hom 'n 'man van dade'. Lukas beskryf Jesus as 'n 'profeet kragtig in werk en woord' en Josefus beskryf Jesus in die Testimonium Flavianum as 'n sage (ooфós ávíp) en 'n performer of marvellous deeds (vgl Wilcox 1982:180).

Wat die Hellenistiese wonderliteratuur betref, is baie navorsers die mening toegedaan dat dit die kanonieke Evangelies beïnvloed het. Bultmann (1963:254v) was van mening dat vreemde materiaal die mondelinge sowel as die skriftelike fase van die tradisie gepenetreer het. Hy onderskei verder tussen 'n Palestynse en Hellenistiese fase. Hoewel hy van mening is dat die Palestynse gelowiges reeds verhale oor Jesus se wonders gehoor het, word die wonderverhale in die algemeen aan Hellenistiese invloede toegeskryf. Ook Dibelius is nie onwillig om toe te gee dat wonderverhale van elders aan Jesus toegedig is nie. Dit is moontlik die geval met Markus 5:1-20 (Dibelius 1926:29). Baie ander navorsers is egter onwillig om sulke invloed te aanvaar (vgl bv Van der Loos 1965:136vv).

In samehang met die Hellenistiese agtergrond van die wonders kan Appolonios van Tyana genoem word, asook die hele vraagstelling van Jesus as $\theta \in i o c$ áńp. Appolonios is van belang vir die bestudering van die Nuwe-Testamentiese wonderverhale, aangesien hy min of meer 'n tydgenoot van Paulus was. Sy lewe is beskryf deur sy derde-eeuse biograaf Philostratos. Hy was bekend vir verskeie wonders, waaronder verskeie genesings, eksorsismes en ook 'n opwekking uit die dood. Sonder

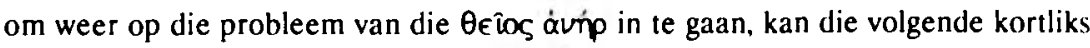
gesê word: Die idee dat Jesus as $\theta \epsilon \hat{i o s}$ ávíp gesien moet word teen die agtergrond van 'n dergelike Hellenistiese idee en dat veral Jesus se wonders teen hierdie agtergrond gesien moet word, is sterk gedebatteer in sekere kringe en verskeie navorsers was voorstanders van die idee. Dit het egter algaande in onguns begin verval, namate dit uit verskeie studies begin duidelik word het dat die $\theta \in i ̂ s$ aump nie so 'n afgegrensde kategorie was as wat aanvanklik geglo is nie. Die algemene gevoel het in- 


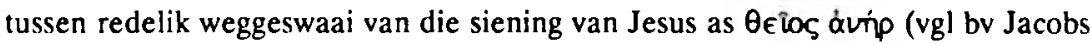
1991:27-54).

Intussen het verskeie navorsers die aandag gevestig op die Ou-Testamentiese agtergrond van die wonders van Jesus. Soos bekend, word veral Moses, Elia en Elisa in die Ou Testament as wonderdoeners voorgestel. As die wonders van Jesus met die wonders van dié wonderdoeners vergelyk word, is daar inderdaad merkwaardige ooreenkomste. Dikwels word daar dan geredeneer dat die Evangelieskrywers met die Ou-Testamentiese wonders in gedagte, Jesus wou voorstel as een wat groter is as die Ou-Testamentiese profete.

Verder van belang is ook die Griekse magie-papiri (vgl Betz 1986). Die vroegste van hierdie papiri dateer uit die eerste eeu, terwyl die meerderheid uit die derde, vierde en vyfde eeu dateer. Die Christelike magie-papiri in die versameling kom hoofsaaklik uit die vyfde en sesde eeu. In die nie-Christelike magie-papiri hang die effektiwiteit af van die veelvuldige goddelike name wat aangeroep word: Adonai, Iao, Psyche, Eros, Osiris, Isis, Anubis, Re, Hermes, Zeus, Helios, Selene, Kore, Iao, Adoni, Logos, Jesus Christus, Heilige Gees, Seun van die Vader (vgl Kee 1989:127). Dit is duidelik dat daar op Griekse, Joodse, Egiptiese en Christelike tradisies staat gemaak word vir die effektiwiteit van die magiese instruksies. In die dokumente wat as Christelike magie-papiri bestempel word, is daar min wat hulle onderskei van die ander in die versameling. Die doel is meestal dieselfde: om 'n huis te vind, om die bose af te weer en om gesond te word.

In die tagtigerjare het twee versamelings Joodse magie-materiaal beskikbaar geword in Engelse vertaling: Sepher-ha-Razim: The book of mysteries en Amulets and magic bowls: Aramaic incantations of late antiquity (vgl Kee 1989:128vv).

Ten opsigte van die onderwerp van magie, is die debat oor Jesus as magiër van belang. Die debat is ons insiens nog geensins afgehandel nie en sal waarskynlik met die aandag wat die wonders in die volgende aantal jare gaan ontvang, weer in die kollig wees. Die debat is reeds deur Hull (1974) begin, of moontlik selfs deur Böcher (1970, 1972a, 1972b) met sy trilogie studies oor die demonologiese agtergrond van die Bybel, en is voortgesit deur die belangwekkende werk van Morton Smith in 1978. Hull gee toe dat Jesus waarskynlik nie aan Homself as 'n towenaar gedink het nie, maar teen die tyd dat die eerste Evangelie geskryf is, was die tradisie oor die optrede van Jesus reeds deurspek met die siening van Hellenistiese magie. Hierdie magiese voorstelling van Jesus is veral prominent in Markus en Lukas-Handelinge en is deur Matteus en Johannes versag. Eksorsismes is volgens Hull onlosmaaklik met magie verbind, en op grond van Jesus se eksorsismes word Hy dan as 'n magiër gesien (vgl Yamauchi 1986:94). 
Ook Morton Smith het 'n trilogie geskryf waarin hy Jesus as magiër probeer bewys, maar dit is veral Jesus the magician (1978) wat aandag getrek het. Die karaktertrekke van 'n magiër op grond waarvan hy Jesus as magiër probeer huldig, is die doen van wonders, die aanspraak op goddelikheid en gebed. Boonop is Jesus gekarakteriseer met kompulsiewe gedrag soos toe Hy deur die Gees na die wildernis gedryf is (Mark 1:12). Die magiese karakter van die Nagmaal dra ook baie by tot Smith se siening. Hy gee toe dat die kanonieke Evangelies Jesus nie as 'n magiër voorstel nie, maar dit is toe te skryf aan die feit dat hulle dit juis probeer verbloem het omdat daar 'n stigma aan die woord 'magiër' gekleef het. Smith het baie kritiek gekry en sy aansluiting by Philostratos se Appolonios van Tyana en die Griekse magie-papiri is deur Kee (1983) as anachronisties bestempel.

Aune (1980) se bydrae tot die debat lê myns insiens daarin dat hy magie in 'n sosiologiese perspektief probeer plaas, veral binne 'n struktureel-funksionele sosiologiese raamwerk. Hy het waardering vir Hull en Smith se werk, maar gaan nie sover om Jesus as 'n magiër te beskou nie. Hy plaas Jesus se magiese aktiwiteite onder die kategorie van 'n messiaanse profeet.

Hoewel die bronne vir die lewe van Jesus - en dan veral vir die hedendaagse interesse sy wonders - in die verlede baie bespreek is en daar sekere tendense met verloop van tyd gekom en gegaan het, is die hele probleem opnuut op die tafel en behoort van nuuts af bestudeer en geëvalueer te word. Veral die groot hoeveelheid relatief nuwe materiaal wat beskikbaar geraak het oor die afgelope aantal dekades hou opwindende moontlikhede in. Reeds het geblyk dat dit die sienings oor die woorde van Jesus noemenswaardig beinvloed het. Heel waarskynlik is dieselfde moontlik ten opsigte van die wonders.

\section{METODE}

Dit is lank nie meer nuus nie dat die historiese ondersoek na die Bybel (en die historiese Jesus) nie alleen op historiese grondslag berus nie, maar met die hulp van ander wetenskappe aangevul word. 'n Belangrike vraag in die Jesus Seminar is die vraag na die verhouding en verantwoordelikheid van die navorsing teenoor die samelewing. By die eerste vergadering van die Seminar het Funk (aangehaal deur Hollenbach 1989:13) daarop gewys dat die basiese vraag die etiese en nie die historiese is nie: 'What do the stories do for us?' Dit is verder gevoer deur Taussig en Kaufman (vgl Hollenbach 1989:13) wat albei op die sosiale verantwoordelikheid van die navorsing wys en daardeur impliseer dat navorsing beinvloed word deur ons kulturele setting. Die gevaar wat daarmee saamhang, is dat elke navorser waarskynlik sy navorsing reeds met 'n vooringenome Jesus-beeld en 'n Jesus-verhaal aanpak. 
In die VSA werk verskillende groepe met die gebruik van die Sosiale Wetenskappe ten opsigte van Bybelinterpretasie. Bruce Malina lei 'n groep in die Catholic Biblical Association, te wete 'The social sciences and second Testament exegesis'. John Pilch is die leier van die Society of Biblical Literature se 'Social sciences and New Testament interpretation'. Voordat hulle weggebreek het, was een van die subseminare van die Westar Institute se Jesus Seminar die 'Social facets seminar' onder leiding van John Elliott. Hierdie groep staan tans bekend as die 'The Context Group-Project on the Bible in its Cultural Environment'. Veral laasgenoemde groep beoog om met hulle publikasies lig te werp op die lewe van antieke Mediterreense mense waaronder die mense van Galilea en Judea, wat Jesus en sy dissipels asook die vroeë Christene insluit. Veral antropologiese ondersoeke en die relatiewe nuwe dissipline van mediese antropologie kan heelwat lig werp op die agtergrond waarteen Jesus se wonders gesien kan word (vgl Hollenbach 1989:14).

In 'n paar onlangse boeke het navorsers reeds probeer om 'n nuwe rigting in te slaan met Historiese Jesus-studies. As agtergrond vir die outentisiteit van Jesus se optrede is hulle van belang, hoewel nie een van hulle werklik die probleem van die historisiteit van Jesus se wonders bespreek nie. Hier word kortliks aandag gegee aan die bydraes van Borg, Oakman en Horsley.

Borg (1984) gee in sy boek Conflict, holiness, and politics in the teachings of Jesus kritiek op die uitsluiting van politiek by die meeste navorsers. Hy redeneer dat religie en politiek nie twee afsonderlike entiteite in die antieke Mediterreense wêreld was nie. Politiek hoort dus nie uitsluitlik tot die party van die Selote nie, maar het 'n wesenlike deel van die daaglikse lewe van elke individu gevorm. Borg gaan voort om die onskeibare interpenetrasie van heiligheid (religie) en politiek in Jesus se optrede aan te toon, byvoorbeeld met betrekking tot die Sabbat en die tempel.

Oakman (1986) se boek Jesus and the economic questions of his day fokus op ekonomiese produksie en verspreiding in Palestina in die tyd van Jesus as konteks vir die verstaan van die ekonomiese dimensie van Jesus se optrede. Hy maak gebruik van ekonomiese antropologie en pas teorieë en modelle toe op die beskikbare data oor Palestina. Aspekte soos eiendomsreg, belasting, huur en skuldenaarskap word ondersoek om die materiële konteks van Jesus se optrede en woorde te verskaf.

Horsley (1987) se boek Jesus and the spiral of violence: Popular Jewish resistance in Roman Palestine kritiseer die hoofstroom-siening van Judaisme en veral die siening van die Selote as die voorstanders van revolusie teen die Romeine teenoor Jesus as 'n groot voorstander van vyandsliefde. Horsley kritiseer verskeie gevestigde sienings as verkeerde konstrukte van navorsers. Dit sluit sienings in oor die Selote, apokaliptiek. geweld, die koninkryk van God, die tempel en sosiale revolusie. 
Dit spreek vanself dat hierdie studies 'n waardevolle bydrae lewer, nie net vir die verstaan van Jesus se woorde nie, maar ook vir sy dade. Die inligting wat hierin ontsluit word, sal in ag geneem moet word by die bestudering van die wonders. Woorde en dade van 'n historiese persoon hang immers onteenseglik saam en kan nie as twee onafhanklike kategorieë bestudeer word nie.

Daar is ook baanbrekerswerk gedoen deur Theissen (1974) en Kee (1983) ten opsigte van die sosiologiese benadering van die wonders. Dit alles tesaam het reeds die grondslag begin lê vir die verdere sosiologiese en antropologiese bestudering van die wonders, wat myns insiens 'n belangrike deel van die historiese ondersoek in die toekoms sal vorm.

'n Ander saak wat vermelding verdien, is die kwessie van kriteria. Die kriteria vir die bepaling van die outentieke woorde van Jesus het nog altyd al die aandag gekry, met die gevolg dat die kriteria vir die bepaling van outentieke wonders in die verlede gewoonlik afgeskeep is. Kan dieselfde kriteria as wat vir die woorde gebruik word byvoorbeeld net so op die wonders oorgedra word? Hoewel die rol van die kriteria deur die meeste navorsers erken word, is daar tog nie eenstemmigheid oor die aantal kriteria nie. So het Boring bevind dat daar tien onderskeibare kriteria in gebruik is deur navorsers, terwyl Polkow bevind het dat daar vyf en twintig is (vgl Hollenbach 1989:15).

Die kriterium van dissimilariteit is waarskynlik die wydste gebruik, maar is nie sonder probleme nie (vgl Hollenbach 1989:15). Stauffer (1982:9) formuleer dit as die bruikbaarste kriterium soos volg: 'Historisch glaubwürdig ist ein Jesuszeugnis am ehesten dann, wenn es weder aus spätjüdischen noch aus frühchristlichen Prämissen ableitbar ist.' Hy gaan verder en gee toe dat hierdie kriterium tot verkeerde gevolgtrekkings kan lei, byvoorbeeld as 'n woord wat aan Jesus toegeskryf word, deur die ontdekking van nuwe manuskripte as eg-Joodse denkproduk sou verskyn. Hy stel dan voor dat daar verder gegaan moet word met hierdie kriterium en doen die volgende reël aan die hand: 'Anspruch auf historische Glaubwürdigkeit haben zunächst einmal diejenigen Jesuszeugnisse, die sowohl für spätjüdisches wie für frühchristliches Denken anstössig sind.' Die Jesus-beeld wat by konsekwente aanwending van hierdie kriterium, wat hy die skandalon-kriterium noem, te voorskyn tree, is 'das Bild eines Nonkonformisten, nicht genug, eines Provokateurs'. So toegepas, is dit egter myns insiens moontlik dat die ooreenkomste van Jesus met die Jodedom van sy tyd en miskien selfs met die vroeë Christendom geïgnoreer kan word en gevolglik tot verkeerde gevolgtrekkings kan lei. In elk geval is dit nie heeltemal duidelik presies hoe die eerste-eeuse Jodedom van die later Jodendom verskil het nie. 
Blomberg (1986:446vv) noem die volgende ses kriteria as die geskikste vir wondernavorsing:

- Veelvoudige getuienis: Wonders kom voor in elke laag en moontlike bron van die kanonieke Evangelietradisie. Hulle kom in verskillende vorme voor en daar word na hulle verwys in die woordtradisie en die primitiewe kerugma soos gereflekteer in Handelinge.

- Palestynse omgewing: Ter ondersteuning verwys Blomberg na die volgende uitspraak: 'Certainly with all other things equal the case for historicity is enhanced if the features and stories in question are conceivable in a Jewish, Aramaicspeaking milieu' (Blackburn 1986:206).

- Toevallige details en tendense van die tradisie: Hiervolgens word oordele oor die historisiteit van verhale gemaak op grond van die 'restrained, unadorned nature of the accounts along with their incidental, true-to-life details' (Blomberg 1986:447). Hy gaan dan voort om te sê dat baie meer genuanseerde studies van die Evangelies uit 'n literêre perspektief nodig is, veral in die lig van die style van fiksie en geskiedskrywing in die antieke wêreld.

- Interne en eksterne koherensie: Hier kan byvoorbeeld gedink word aan samehang met die gelykenisse van Jesus of aan samehang met ander wonders van dieselfde aard. Verder ook aan samehang met nie-Christelike getuienis van Jesus se wonders, byvoorbeeld Josefus en die Talmud.

* Afwykende patrone van redaksie: Met die toerekening van enkele woorde of frases aan die evangelis of die tradisie word dikwels op dun ys beweeg, veral ten opsigte van pre-Markaanse en pre-Johannese materiaal. Ten opsigte van breër temas en konsepte kan egter dikwels op meer vaste grond beweeg word.

* Dissimilariteit: Hier kom die verhouding van die wonders met parallelle in die antieke wêreld ter sprake. Selfs al het Jesus geen wonders gedoen nie, moet 'n verklaring gesoek word vir die ontstaan van die verhale wat vertel dat $\mathrm{Hy}$ dit wel gedoen het. Die vier bronne wat die meeste hiervoor gebruik word, is die apokriewe evangelies, verhale van Grieks-Romeinse helde, beskrywings van magie en magiërs in die antieke en die antieke Joodse verwysings na charismatiese heiliges in Palestina.

Die vraag is of hierdie kriteria bruikbaar en voldoende is. Laat hulle genoeg ruimte vir Jesus as individu sowel as groepsmens van sy tyd? Laat hulle genoeg ruimte vir Jesus as Jood sowel as 'stigter' van die Christendom? Dit is myns insiens nodig dat die hele kwessie van kriteria ten opsigte van die wonders weer indringend onder- 
soek moet word. Die besluite wat die Jesus Seminar in dié verband gaan neem, word met afwagting ingewag.

\section{HISTORISITEIT VAN VERSKILIENDE SOOR'TE WONDERS}

Die belangrikste besprekingspunte in die debat oor die historisiteit van die wonders word nou aan die orde gestel. Sommige navorsers verdedig die historisiteit van beide die genesingswonders en natuurwonders, terwyl andere slegs die historisiteit van die genesingswonders aanvaar.

\subsection{Eksorsismes}

Dat Jesus as eksorsis opgetree het, berus volgens baie navorsers op 'n redelik vaste historiese grondslag. Ten gunste van die historisiteit van die eksorsismes word die volgende aangevoer (vgl Twelftree 1986:362vv):

Eerstens, die getuienis van die eksorsismeverhale in die Evangelies. Hiervan voorsien Markus vier (1:21-28; 5:1-20; 7:24-30; 9:14-29), terwyl $Q$ die enigste ander kort eksorsismeverhaal in die evangelietradisie voorsien (Matt 9:32-33/12:2224/Luk 11:14).

Tweedens bevat die Sinoptiese Evangelies uitsprake van Jesus wat sy eksorsismes veronderstel. Daar is ten minste twee gedeeltes waar Jesus na sy eksorsismes verwys en altwee dui op sy sukses as eksorsis: Matteus 12:27v/Lukas 11:19v en Markus 3:28v. Dit wil voorkom of $Q$ en die evangeliste 'n hele paar uitsprake in dié verband saamgegroepeer het:

* Die Beëlsebul-aanklag en Jesus se antwoord - Markus 3:22-26 en die Q-parallel Matteus 12:24-26/Lukas 11:15-18 (Crossan ,no 424);

- Die Gees/vinger van God-uitspraak wat net in Q opgeteken is - Matteus 12: 27v/Lukas 11:19v (Crossan no 136);

- Die sterk man-uitspraak - Markus 3:27/Matteus 12:29, met die Q-weergawe in Lukas 11:21v (Crossan no 137, vgl die Evangelie volgens Thomas se uitspraak)

- die blasfemie-uitspraak - Markus 3:28v/Matteus 12:31, 32b, met sy Q-parallel wat deur Lukas in 'n ander konteks oorgelewer is - Lukas 12:10/Matteus 12:32 (Crossan no 139, vgl die Evangelie volgens Thomas en die Didache).

Al hierdie uitsprake dui op 'n konteks van kontroversie oor Jesus se werk as 'n eksorsis.

Derdens is daar in die Sinoptiese Evangelies en Handelinge opsommingsberigte van Jesus se bediening. Markus 1:32-34 (Matt 8:16-17/Luk 4:40-41), Markus 1:39 (Matt 4:24/Luk 4:44) en Markus 3:7-12 (Matt 4:24-25; 12:15-16/Luk 6:16-19; 4:41) 
maak melding van Jesus se eksorsismes. Hierby kan Lukas 7:21 en Handelinge 10: 38 gevoeg word.

Vierdens het eksorsiste blykbaar in die Nuwe-Testamentiese era gebruik gemaak van die name van ander eksorsiste met hoë aansien. So is Salomo in hierdie tyd gesien as 'n groot eksorsis (vgl Pseudo-Filo LAB 60 en Josefus Ant 8:45-49). In laasgenoemde gebruik Eleazar die naam van Salomo by 'n eksorsisme. Soortgelyk hieraan vertel die Nuwe Testament dat Jesus se naam deur ander eksorsiste gebruik word (bv Mark 9:38; Luk 9:49) waar Johannes aan Jesus sê: 'Ons het iemand gesien wat duiwels in u Naam uitdryf....' As hierdie woorde as histories korrek bewys word, getuig dit van die feit dat Jesus as 'n eksorsis van aansien beskou is.

Vyfdens is daar die getuienis buite die Nuwe Testament, soos die formule in die magie-papiri wat deur eksorsiste gebruik is: 'Ek besweer jou deur die God van die Hebreërs, Jesu.' In die sensurering van Jesus se naam deur die Jode is moontlik verdere getuienis dat Jesus deur hulle as 'n kragtige geneser gesien is (vgl Twelftree 1986:367).

\subsection{Genesings}

Jesus se reputasie as ' $n$ wonderwerker word beskryf in charismatiese terme en is duidelik teenwoordig in die vroegste bronne (vgl Dunn 1975:70). Hier kan veral verwys word na die gebruik van die woord $\delta$ uáuels. Veral in Hellenistiese kringe het die

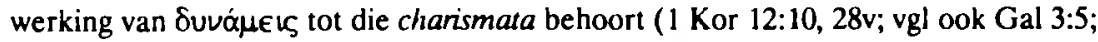

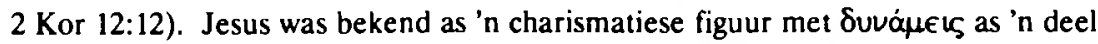
van sy bediening - vergelyk Handelinge 2:22 waar Jesus in Petrus se toespraak op

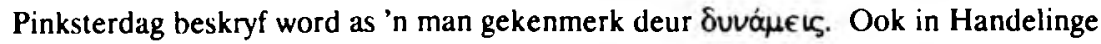
10:37v kom woorde in dieselfde trant in die mond van Petrus voor. Daarbenewens

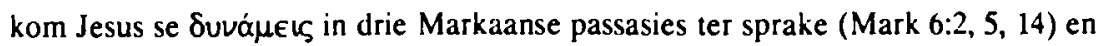
in een Q-passasie (Matt 11:21, 23 en Luk 10:13). Die Handelinge- en Markus-passasies rus almal op goeie tradisie op grond van hulle tipies Joodse uitkyk, naamlik dat God die eintlike doener van die magtige dade is. Die Q-passasie is die enigste plek waar Jesus self sy optrede in terme van magtige dade beskryf. Die uitspraak se egtheid kan op verskeie gronde verdedig word, byvoorbeeld die talle tradisies van Jesus se wonderaktiwiteit in die omstreke van die See van Galilea en ooreenkoms met Jesus se ander apokaliptiese uitsprake. Wat verder opval ten opsigte van hierdie uitspraak, is die feit dat hier geen melding gemaak word van prediking in Gorasin en Betsaida nie, met ander woorde die oordeel oor die twee dorpe gaan slegs oor hulle reaksie op die magtige dade wat in hulle plaasgevind het, hoewel Jesus waarskynlik sy prediking as sy vernaamste werk gesien het (Matt 11:5). 
Wat presies ingesluit is onder Jesus se $\delta v v a ́ \mu \in \mathrm{L}_{\text {, }}$ is nie heeltemal duidelik nie. Dunn (1975:71) is van mening dat geeneen van Jesus se genesings buite die kategorie van psigo-somatiese kwale val nie (vgl Matt 11:5). In die godsdiensgeskiedenis is talle parallelle van hierdie soort genesings. Soos vroeër gesê is, kan Jesus se wonders opnuut ondersoek word met behulp van byvoorbeeld 'n dissipline soos mediese antropologie.

\subsection{Natuurwonders}

Soos hierbo genoem is, is baie navorsers bereid om die historisiteit van die eksorsismes en die genesings deur Jesus te aanvaar. Navorsers het egter heelwat meer probleme as dit by die natuurwonders kom. Slegs 'n paar argumente wat in die bespreking van die historisiteit ter sprake kom, word hier genoem.

Terwyl daar rede is om te glo dat Jesus se eie woorde verwys na sy genesings, kan dieselfde nie gesê word van die sogenaamde natuurwonders nie. Daar kan ge-

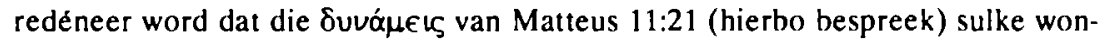
ders insluit (vgl bv 1 Kor 12:9v waar dit lyk of Paulus onderskei tussen 'genadegawes van gesondmaking' en 'werkinge van kragte'), maar dit is nie heeltemal duidelik wat

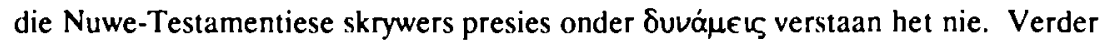
word daar nie gesê dat een van die natuurwonders in Gorasin en Betsaida plaasgevind het nie ( $\mathrm{vgl}$ hier bo). Waarskynlik is twee (egte?) Jesus-woorde uitgebrei om verwysings na natuurwonders in te sluit, naamlik Markus 8:15, 'Pas op, wees op julle hoede vir die suurdeeg van die Fariseërs en die suurdeeg van Herodes', met die oog op die voedingwonders, en Markus 11:22v waar 'n aanmoediging tot geloof by die vervloeking van die vyeboom gevoeg is.

Dunn (1975:72) is van mening dat Markus 11:23v nie geïgnoreer kan word nie, al wys die variante vorme van die uitspraak in Matteus 17:20 en Lukas 17:6 daarop dat die uitspraak geen definitiewe Sitz im Leben in die tradisies oor Jesus gehad het nie: 'Want, voorwaar Ek sê vir julle dat elkeen wat vir hierdie berg sê: Hef jou op en werp jou in die see - en nie in sy hart twyfel nie, maar glo dat wat hy sê, sal gebeur hy sal verkry net wat hy sê.' Volgens Dunn kan hierdie woord dui op 'n oortuiging by Jesus dat die geestelike kragte aan die werk in Hom en deur Hom die gang van die natuur kan beïnvloed en verander. Hy noem dan die moontlikheid dat die mag en die krag van 'n charismatiese persoonlikheid aan sommige van die naturwonders ten grondslag kan lê. Die wandeling op die water kan byvoorbeeld aan die hand van die psigiese fenomeen van operatio in distans (sic) verklaar word (eerder as die moontlikheid van levitasie). 
Daar is egter navorsers wat die historisiteit van die natuurwonders, of ten minste sommige daarvan, verdedig. So byvoorbeeld verdedig Barnett (1986:289) die historisiteit van die broodvermeerdering op grond van sy bevinding dat die weergawes van Markus en Johannes nie afhanklik van mekaar is nie, maar elkeen selfstandig ontstaan het op grond van ooggetuieverslae.

\section{SLOT EN GEVOLGTREKKINGS}

Nadat daar in die Nuwe-Testamentiese navorsing vir etlike dekades 'n groot windstilte ten opsigte van die historiese Jesus was, het daar in die afgelope paar jaar interessante en opwindende winde van verandering begin waai. Die nuwe navorsing is met nuwe ywer en gesigpunte aangepak in die lig van nuwe beskikbare materiaal, en merkwaardige resultate is reeds behaal. Die vak Nuwe Testament is ingrypend geraak deur die verbreding van die materiaal waarmee gewerk word. So werp die nuwe Red-letter edition van die Evangelies 'n nuwe blik op Jesus en het die fokus van Jesus as eskatologiese profeet verskuif na Jesus die wysheidsleraar. Verder het die siening van die Joodse samelewing in die tyd van Jesus en waarvan Jesus 'n onlosmaaklike deel was, die afgelope paar jaar dramaties verander van 'n geïntegreerde eenheidsamelewing tot 'n bonte verskeidenheid waarvan slegs uit alle moontlike bronne ' $n$ indruk gekry kan word. Hierdie mosaïek moet nog saamgevoeg word. Te midde van dit alles lê 'n opwindende tyd van navorsing oor Jesus se wonderdade voor. 'Nuwe' materiaal kan as bronne gebruik word en nuwe metodes van ondersoek kan met behulp van ander wetenskappe ingespan word. In die proses sal baie van die ouer vrae en sienings in 'n nuwe lig bekyk moet word. Ongetwyfeld sal deur dit alles 'n duideliker beeld na vore tree van dié dade wat deur die eeue heen vir party tot ergernis en vir ander weer tot groot inspirasie in die Evangelies opgeteken staan.

\section{Literatuurverwysings}

Aune, D 1980. Magic in early Christianity. ANRW 23/2, 1507-1557.

Barnett, PW 1986. The feeding of the multitude in Mark 6/John 6, in Wenham, D \& Blomberg, C (eds). 1986: 273-293.

Betz, H-D 1986. The Greek magical papyri in translation, including the Demotic spells. Chicago: University of Chicago.

Blackburn, B I. 1986. 'Miracle working $\Theta E I O I$ AN $\triangle P E \Sigma$ ' in Hellenism (and Hellenistic Judaism), in Wenham \& Blomberg 1986: 185-219.

Böcher, O 1970. Dämonenfurcht und Dämonenabwehr. Stuttgart: Kohlhammer. 
Böcher, O 1972a. Das Neue Testament und die dämonischen Mächte. Stuttgart: Katholisches Bibelwerk.

--- 1972b. Christus Exorcista. Stuttgart: Kohlhammer.

Borg, M J 1984. Conflict, holiness and politics in the teachings of Jesus. Lewiston: Edwin Mellen. (Studies in the Bible and early Christianity 5.)

Bultmann, R 1963. The history of the synoptic tradition. Oxford: Blackwell.

Cameron, R 1982. The other Gospels: Non-canonical Gospel texts. Philadelphia: Westminster.

Charlesworth, J H 1982. The historical Jesus in light of writings contemporaneous with him. ANRW 25/1, 451-476.

Crossan, J D 1986. Sayings parallels: A workbook for the Jesus tradition. Philadelphia: Fortress.

--- 1988. Materials and methods in historical Jesus research. Forum 4, 3-24.

Dibelius, M 1926. Geschichte der urchristlichen Literatur. Leipzig: Kaiser.

--- 1933. Die Formgeschichte des Evangeliums. 2 Aufl. Tübingen: Mohr.

Dunn, J D G 1975. Jesus and the Spint. London: SCM.

Fiebig, P 1911. Jüdische Wundergeschichten des neutestamentlichen Zeitalters unter besonderer Benücksichtigung ihres Verhältnisses zum Neuen Testament. Tübingen: Mohr.

Hedrick, C W 1988. The tyranny of the synoptic Jesus. Semeia 44, 1-8.

Hollenbach, P 1982. The conversion of Jesus: From Jesus the baptizer to Jesus the healer. $A N R W 25 / 1,196-219$.

Hollenbach, P 1989. The historical Jesus question in North America today. Biblical Theology Bulletin 19, 11-22.

Horsley, R A 1987. Jesus and the spiral of violence: Popular Jewish resistance in Roman Palestine. San Francisco: Harper \& Row.

Hull, J M 1974. Hellenistic magic and the synoptic tradition. London: SCM.

Jacobs, M M 1991. Tendense in die navorsing oor Markus se Christologie sedert William Wrede. DTh proefskrif, Universiteit van Suid-Afrika.

Kee, H C 1983. Miracle in the early Christian world: A study in socio-historical method. New Haven: Yale University.

--- 1989. Magic and Messiah, in Neusner, J, Frerichs, E S \& Flesher, P V M (eds), Religion, science and magic. New York: Oxford University Press.

Oakman, D 1986. Jesus añd the economic question of his day. Lewiston: Edwin Mellen.

Robinson, J M 1988. The study of the historical Jesus after Nag Hammadi. Semeia 44, 45-55.

Smith, M 1978. Jesus the magician. San Francisco: Harper \& Row. 
Stauffer, E 1982. Jesus, Geschichte und Verkündigung. ANRW 25/1, 3-130.

Theissen, G 1974. Urchristliche Wundergeschichten: Ein Beitrag zur formgeschichtlichen Erforschung der synoptischen Evangelien. Gütersloh: Mohn. (StNT 8).

Twelftree, G 1986. El $\triangle E$...E $\Omega$ EKBA $\wedge \Omega$ TA $\triangle A I M O N I A . .$. in Wenham \& Blomberg 1986:361-400.

Vermes, G 1973. Jesus the Jew: A historian's reading of the Gospels. London: Collins. Van der Loos, H 1965. The miracles of Jesus. Leiden: Brill. (Supplements to Novum Testamentum.)

Wenham, D \& Blomberg, C (eds) 1986. Gospel perspectives: The miracles of Jesus, vol 6. Sheffield: JSOT.

Wilcox, M 1982. Jesus in the light of his Jewish environment. ANRW 25/1, 131-195.

Yamauchi, E 1986. Magic or miracle?: Diseases, demons and exorcisms, in Wenham \& Blomberg 1986:89-183. 